\title{
ANALISIS PERILAKU WORD OF MOUTH WISATAWAN TAMAN REKREASI KOTA PEKANBARU: TINJAUAN DARI ASPEK SERVICE QUALITY DAN COSTUMER SATISFACTION
}

\author{
Qomariah Lahamid \\ (Dosen Fekonsos UIN Suska Riau)
}

\begin{abstract}
Abstrak
Penelitian ini membahas hubungan antara kualitas pelayanan, kepuasandan word of mouth (WOM) wisatawan tamanrekreasi kota Pekanbaru. Adapun tujuan penelitian ini yaitu 1) Untuk mengetahui service quality dan costumer satisfaction wisatawan taman rekreasi kota Pekanbaru. 2) Untuk mengetahui pengaruh yang signifikan antara service quality dengan perilaku WOM wisatawan tamanrekreasi kota Pekanbaru. 3) Untuk mengetahui pengaruh yang signifikan antara costumer satisfaction dengan perilaku WOM wisatawan tamanrekreasi kota Pekanbaru. 4) Untuk mengetahui pengaruh yang signifikan antara service quality dengan costumer satisfaction wisatawan taman rekreasi kota Pekanbaru.

Sampel dalam penelitian ini sebanyak 248 responden yang diambil dengan teknik purposive samplingdengan kriteria telah pernah mengunjungi minimal dua taman rekreasi yang ada di kota Pekanbaru. Penelitian ini menggunakan analisisStructural Equation Modelling (SEM) dengan aplikasi software Analysis Moment of Structure (AMOS) dan Special Package for Statistis Science (SPSS).

Hasil penelitian menunjukkan bahwa : 1) Service qualityberpengaruhsignifikan terhadapperilaku WOM wisatawan taman rekreasi kota Pekanbaru. 2) Costumer satisfactionberpengaruh signifikan terhadap perilaku WOM wisatawan taman rekreasi kota Pekanbaru. 3) Service qualityberpengaruh signifikan terhadapcostumer satisfaction wisatawan taman rekreasi kota Pekanbaru.
\end{abstract}

Kata kunci :Service Quality, Costumer Satisfaction dan Word Of Mouth (WOM)

\section{PENDAHULUAN}

Perusahaan-perusahaan yang bergerak di sektor industri pariwisata, merupakan perusahaan yang memproduksi jasa dalam bentuk jasa wisata sebagai produk utamanya. Industry pariwisata bukanlah industry yang berdiri sendiri, tetapi merupakan serangkaian perusahaan yang menghasilkan jasa atau produk yang berbeda satu sama lain (Schomll dalam Yoeti, 1996:1).

Industri pariwisata saat ini merupakan industri yang cukup menjanjikan profit besar bagi pengusaha. Mengingat masyarakat selaku konsumen membutuhkan hiburan melalui pariwisata di setiap daerah. Mereka rela mengorbankan bahkan mengalokasikan dengan sengaja dana untuk bisa berwisata.

Begitu juga dengan kota Pekanbaru. Industri pariwisata mulai dilirik oleh para pengusaha. 
Mengingat even-even regional, nasional bahkan internasional telah dan akan dilaksanakan di kota Pekanbaru. Contoh saja even nasional yang baru dilaksanakan yaitu Pesta Olah Raga Nasional (PON) XVIII pada tahun 2012.

Tabel. 1.

Tempat Wisata KotaPekanbaru

\begin{tabular}{ll}
\hline No & \multicolumn{2}{c}{ Tempat Wisata } \\
\hline 1 & Taman Rekreasi Puteri Kaca Mayang \\
2 & Taman Rekreasi Ala Mayang \\
3 & Taman Rekreasi Danau Buatan \\
4 & Mesjid Agung An Nur \\
5 & Mesjid Raya \\
6 & Pustaka Soeman HS \\
7 & Balai Adat Riau \\
8 & Dekranasda Riau \\
9 & Padang Golf \\
10 & Bandar Serai Raja Ali Haji \\
11 & Pondok Durian \\
12 & Pusat Jagung Bakar \\
13 & Taman Makam Pahlawan Kusuma Dharma \\
14 & Tugu pahlawan dan Monumen Lokomotif \\
15 & Mall Pekanbaru \\
16 & Mall SKA \\
17 & Mall Ciputra \\
18 & Senapelan Plaza \\
19 & Pasar Bawah \\
20 & Museum daerah Provinsi Riau \\
21 & Labersa Water Park \\
22 & Aras Water Park \\
\hline Sumber: Majalah Visit Riau 2010 (Informasi \\
dan Panduan Wisata Riau) \\
Ada beberapa tempat wisata \\
yang menjadi tempat wisatakota \\
Pekanbaru. Pada tabel 1 tampak \\
bahwa ada tiga taman rekreasi yang \\
dimiliki oleh kota Pekanbaru yaitu \\
taman rekreasi Alam Mayang \\
dikelola oleh swasta, Taman \\
Rekreasi Danau Buatan dan Taman \\
Rekreasi Kaca Mayang dikelola oleh \\
pemerintah. \\
memperlihatkan jumlah pengunjung \\
taman rekreasi kota Pekanbaru \\
(Alamayang) mengalami turun naik \\
yang cukup signifikan (tabel 2). \\
\end{tabular}

Kemudian fenomena yang berkembang menunjukkan taman rekreasi di kota Pekanbaru juga tidak menjadi incaran wisatawan dalam dan luar dari kota Pekanbaru. Wisatawan yang berkunjung ke taman rekreasi jarang sekali menginformasikan tentang taman rekreasi ini. Bisa dikatakan rendahnya perilaku word of mouth (WOM) pengunjung setelah berkunjung ke tempat wisata.

Tabel 2..

Jumlah Pengunjung TamanRekreasi Alamayang Tahun 2011 dan 2012

\begin{tabular}{lrrrr}
\hline \multicolumn{1}{c}{ Tahun } & \multicolumn{2}{c}{$\mathbf{2 0 1 1}$} & \multicolumn{2}{c}{$\mathbf{2 0 1 2}$} \\
\hline \multicolumn{1}{c}{ Bulan } & Dewasa & Anak & Dewasa & Anak \\
\hline Januari & 25196 & 3651 & 27425 & 3983 \\
Februari & 14065 & 1320 & 10124 & 814 \\
Maret & 12645 & 1248 & 12470 & 1120 \\
April & 12831 & 1340 & 16443 & 1553 \\
Mei & 17773 & 2123 & 15653 & 1923 \\
Juni & 21687 & 3062 & 20246 & 3049 \\
Juli & 22206 & 3700 & 18200 & 3265 \\
Agus & 5553 & 865 & 53848 & 14847 \\
September & 51975 & 9144 & 13636 & 1491 \\
Oktober & 11710 & 1029 & 13870 & 1518 \\
November & 10932 & 963 & 11559 & 1103 \\
Desember & 15924 & 2858 & 32963 & 6741 \\
Jumlah & $\mathbf{2 2 2 4 9 7}$ & $\mathbf{3 1 3 0 3}$ & $\mathbf{2 4 6 4 3 7}$ & $\mathbf{4 1 4 0 7}$ \\
$\quad$ Sumber: Taman Rekreasi Alamayang & \\
& & & &
\end{tabular}

Menurut Blodget (1993); Brown \& Beltramini (1989), Richins (1983); Wilson \& Peterson (1989), bahwa word-of-mouth communication sering dihubungkan dengan kepuasan atau ketidakpuasan konsumen dengan pengalaman konsumsinya terdahulu.Konsumen juga berupaya untuk melakukan WOM untuk memuaskan kebutuhan informasi personal mereka (Bloch, 
1986; Burnkrant and Cousineau, 1975; Cohen \& Golden, 1972; Howard \& Sheth, 1969; Fincus \& Waters, 1977, dalam Mangold, 1999; 74).

Berdasarkan fenomena di atas penulis beranggapan bahwa kualitas pelayanan dan kepuasan konsumen tidak dirasa nyata.Oleh karena itu, penulis ingin mengetahui lebih dalam tentang service quality dan costumer satisfactiondalam menimbulkan perilaku word of mouth wisatawan tamanrekreasi kota Pekanbaru.

Bertitik tolak dari hal tersebut, maka dirumuskan beberapa masalah pokok yang perlu mendapat kajian secara mendalam adalah:

1. Bagaimana service quality dan costumer satisfactionwisatawan taman rekreasi Kota Pekanbaru?

2. Apakah terdapat pengaruh yang signifikan antara service quality terhadap perilaku word of mouthwisatawan taman rekreasi Kota Pekanbaru?

3. Apakah terdapat pengaruh yang signifikan antara costumer satisfaction terhadap perilaku word of mouthwisatawan taman rekreasikota Pekanbaru?

4. Apakah terdapat pengaruh yang signifikan antara service quality dan costumer satisfaction terhadap perilaku word of mouthwisatawan taman rekreasikota Pekanbaru?

Tujuan yang ingin dicapai dari penelitian ini adalah untuk mengetahui:

1. Service quality dan costumer satisfactionwisatawan taman rekreasikota Pekanbaru
2. Pengaruh yang signifikan antara service quality dengan perilaku WOM wisatawan taman rekreasikota Pekanbaru.

3. Pengaruh yang signifikan antara costumer satisfaction dengan perilaku WOM wisatawan taman rekreasikota Pekanbaru.

4. Pengaruh yang signifikan antara service qualitydengan costumer satisfaction wisatawan taman rekreasikota Pekanbaru.

\section{TINJAUAN PUSTAKA}

\section{Service Quality (Kualitas Pelayanan)}

Menurut Lovelock (2001 ; 120), kualitas pelayanan merupakan dasar bagi pemasaran jasa karena produk inti yang dipasarkan adalah kinerja. Seperti yang ditegaskan oleh Parasuraman (1991 ; 5), "the performance is the product; the performance is what customers buy. A strong service concept builds competitiveness be earning customers' confidence and reinforcing, advertising, selling and pricing".

Kualitas jasa pada dasarnya menggambarkan sejauh mana jasa yang dirasakan pelanggan (service performance) dapat memenuhi harapan mereka (customer expectation). Zeithaml (2000; 81), mengungkapkan bahwa kualitas jasa merupakan komponen sangat penting dari persen konsumen. Dalam kasus jasa murni, kualitas merupakan elemen dominan dalam evaluasi yang dilakukan pelanggan.Dalam kasus dimana jasa yang ditawarkan adalah kombinasi dengan produk fisik, kualitas jasa penting dalam menentukan kepuasan pelanggan. 
Ada lima dimensi pokok kualitas jasa yang dinilai yaitu (zeithaml, 2000 ;82): Reliability, Responsiveness, Assurance, Empathy, Tangibles

\section{Kepuasan Konsumen}

Kotler dan Keller (2007) mendefinisikan kepuasan konsumen adalah "Customer satisfaction is the level of a person's felt state resultating from comparing a product's perceived performance (or outcome) in relation tothe person's expectation".

Kepuasan menurut Zeithaml (2000; 75) dapat didefinisikan sebagai berikut:

"Satisfaction is the consumer's fulfilment response. It is a judgement that a product or a service feature, or the product or service itself, provides a pleasurable level of consumption related fulfilment".

Menurut Lovelock (2001 ; 120) kepuasan adalah sikap, yang dapat dilihat dalam bentuk pendapat yang mengikuti suatu tindakan pembelian atau seperangkat interaksi antara konsumen dengan produk yang mereka konsumsi.

\section{Perilaku}

\section{Communication}

Word-of-Mouth

Harrison-Walker dalam Brown et al. (2005) menyatakan bahwa WOM merupakan sebuah komunikasi informal diantara seorang pembicara yang tidak komersil dengan orang yang menerima informasi mengenai sebuah merek, produk, perusahaan atau jasa. WOM dapat diartikan sebagai aktifitas komunikasi dalam pemasaran yang mengindikasikan seberapa mungkin customer akan bercerita kepada orang lain tentang pengalamannya dalam proses pembelian atau mengkonsumsi suatu produk atau jasa. Pengalaman customer tersebut dapat berupa pengalaman positif atau pengalaman negatif. Seperti yang dinyatakan Davidow (2003):

"that word of mouth is actually a $U$ shaped relationship, where satisfiedcomplainers spread positive word of mouth valance, and dissatisfiedcomplainers spread negative word of mouth valance".

Bahwa sebenarnya hubungan dari mulut ke mulut berbentuk $\mathrm{U}$, di manaapabila seseorang puas maka ia akan menyebarkan berita positif dari mulut kemulut, tapi apabila mengeluh tidak puas maka ia akan menyebarkan berita negative dari mulut ke mulut. Pengalaman yang kurang memuaskan pada customer dapatmemunculkan berbagai respon kepada perusahaan. Perusahaan dapat menanggapirespon tersebut dengan berbagai cara yang dinamis. Peluang meningkatnyaaktifitas WOM tersebut dapat memberikan pengaruh yang hebat.

\section{Service Quality dan Words of Mouth}

ChaniotakisdanLymperopoulus (2009) dalam penelitiannya melakukan penerapan SERVQUAL dan dimensi yang digunakan pada penelitian mengacu pada studi yang dilakukan oleh Parasuraman et al. (1988) mengenai kualitas pelayanan.Penelitian ini mengindikasikan bahwa disamping kepuasan, dimensi kualitas layanan secara langsung mempengaruhi WOM adalah empati.Dan selain empati, dimensi tanggapan, jaminan 
dan penampilan berpengaruh tidak langsung terhadap WOM melalui kepuasan.

\section{Costumer Satisfaction dan WOM}

Kotler dan Keller (2007) juga mendukung pendapat tersebut dengan menyampaikan pendapatnya bahwa harapan pelanggan terhadap suatu jasa dapat terbentuk oleh pengalaman masa lalu, WOM, dan promosi yang dilakukan oleh perusahaan jasa.

Kepuasan konsumen menurut Zeithaml akan dipengaruhi oleh fitur spesifik dari produk atau jasa dan persepsi terhadap kualitas. Kepuasan juga akan dipengaruhi oleh respon emosi konsumen, atribusi mereka, dan persepsi mereka terhadap kewajaran, seperti terlihat pada gambar berikut:

\section{Gambar 1}

Customer Perception of Quality and Customer Satisfaction

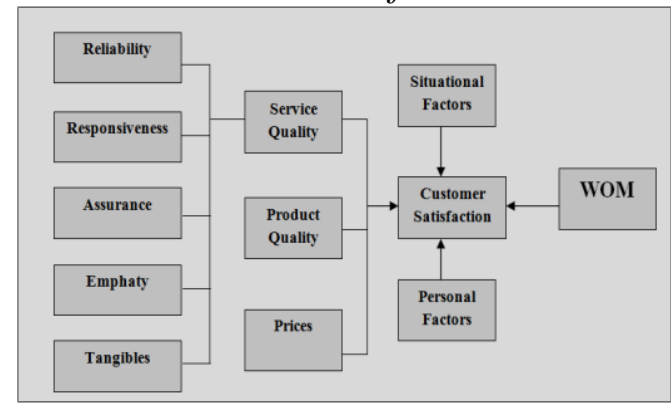

Sumber: Zeithaml (2000 ; 75)

\section{Hipotesis}

1. Diduga service quality berpengaruh signifikan terhadap perilaku $W O M$ wisatawan taman rekreasikota Pekanbaru.

2. Diduga costumer satisfaction berpengaruh signifikan terhadap perilaku WOM wisatawan taman rekreasikota Pekanbaru.
3. Diduga

service qualityberpengaruh signifikan terhadap costumer satisfaction wisatawan taman rekreasikota Pekanbaru.

\section{METODE PENELITIAN \\ Objek Penelitian}

Varibel adalah objek penelitian atau apa yang menjadi titik perhatian suatu penelitian. Objek dalam penelitian ini adalah service quality (kualitas pelayanan), costumer satifaction (kepuasan konsumen) dan Perilaku Word of Mouth. Jenis penelitian ini yaitu explanatory research dengan pendekatan kausalitas

\section{Populasi dan Sampel}

Populasi sebagai keseluruhan unit analisis dalam hal ini adalah wisatawan taman rekreasikota Pekanbaru yaitu: taman rekreasi Alam Mayang, taman rekreasi Kaca Mayang, dan taman rekreasi Danau Buatan.

Sampel adalah bagian dari jumlah populasi yang dimiliki oleh populasi tersebut (Sekaran, 2006).Sesuai dengan alat analisis yang digunakan yaitu Structural Equation Modelling (SEM), maka penemuan jumlah sampel yang representatif menurut Ferdinand (2002) adalah jumlah indikator dikalikan 5 sampai dengan 10 . Jumlah indikator yang digunakan dalam penelitian ini adalah 34 maka ukuran sampel yang dapat digunakan sebagai berikut: .

Sampel minimum $=$ Jumlah indikator $X 5=34$ X $5=170$ responden.

Sampel maksimum $=$ Jumlah indikator $X 10=34$ X $10=340$ responden. 
Berdasarkan pertimbangan di atas peneliti menggunakan sampel sebanyak 250 responden. Teknik penarikan sampling yang digunakan yaitu purposive sampling dengan kriteria responden telah pernah berkunjung minimal dua tempat taman rekreasi tersebut di atas.

\section{Teknik Pengumpulan data}

Dalam penelitian ini data dikumpulkan dengan kuesioner, studi lapangan, studi dokumentasi, dan wawancara mendalam.

Tipe pertanyaan dalam kuesioner adalah pertanyaan tertutup dan terbuka.Pada pertanyaan tertutup, responden diminta untuk membuat pilihan diantara serangkaian alternatif yang diberikan oleh peneliti (Sekaran, 2006).Skala data jawaban responden atas pertanyaan penelitian dengan menggunakan Agree-Disagree Scale yang menghasilkan jawaban sangat tidak setuju - jawaban sangat setuju dalam rentang nilai 1 s/d 10 (Ferdinand, 2006).

Sangat

Tidak Setuju

Sangat

Setuju

\section{$\begin{array}{llllllllll}1 & 2 & 3 & 4 & 5 & 6 & 7 & 8 & 9 & 10\end{array}$}

Penggunaan skala 1-10 ini dipilih dengan pertimbangan untukmenghindari jawaban responden yang cenderung memilih jawaban di tengahsehingga akan menghasilkan respon yang mengumpul ditengah (grey area).Sedangkan untuk pertanyaan terbuka digunakan untuk memperolehtanggapan, pendapat atau ide responden secara bebas yang berguna untukmendukung jawaban responden atas pertanyaan tertutup.

\section{Metode Pengujian Data Uji Validitas (Test of Validity)}

Uji validitas dimaksudkan untuk mengukur sejauh mana instrumen yang digunakan benarbenar mengukur apa yang seharusnya diukur (Cooper dan Schindler, 2001). Validitas juga berhubungan dengan ketepatan alat ukur untuk melakukan tugasnya mencapai sasaran (Hartono, 2004).Penelitian ini menggunakan korelasi bivariate untuk menguji validitas instrumen penelitian.

\section{Uji Reliabilitas (Test of Reliability)}

Suatu kuesioner dikatakan reliabel atau handal jika jawaban responden terhadap pernyataan adalah konsisten atau stabil dari waktu ke waktu. Dalam penelitian ini ketentuan yang digunakan untuk menilai reliabilitas mengikuti rule of thumbyaitu Cronbach Alpha harus lebih besar dari 0.70 (Hair, et. all).

\section{Metode Analisis Data Analisis Deskriptif}

Scoring yang dilakukan dalam penelitian ini adalah minimum 1 dan maksimum 10, maka perhitungan indeks jawaban responden dilakukan dengan rumus sebagai berikut (Ferdinand, 2006, ):

NilaiIndex

$=\frac{\{(\% F 1 \times 1)+(\% F 2 \times 2)+(\% F 3 \times 3)+\cdots+(\% F 10 \times 10)\}}{10}$

Keterangan:

$\mathrm{F} 1=$ frekuensi responden yang menjawab 1

$\mathrm{F} 2$ = frekuensi responden yang menjawab 2

Dan seterusnya, $\mathrm{F} 10=$ frekuensi responden yang menjawab 10 
Adapun kategori nilai indeks yang dihasilkan adalah :

$10.00-28.00=$ Sangat Rendah

$28.01-46.00=$ Rendah

$46.01-64.00=$ Cukup

$64.01-82.00=$ Tinggi

$82.01-100.00=$ Sangat Tinggi

\section{Analisis Inferensial}

Beberapa asumsi Structural Equation Modelling (SEM):

\section{Uji Kecukupan Sampel}

Secara umum, jumlah sampel diatas 200 telah memadai untuk diuji menggunakan SEM. Menurut Hair et. all.,(1998) jumlah sampel minimum adalah 100 dan dinilai telah memenuhi kriteria minimal lima kali jumlah estimated parameter.

\section{Uji Normalitas}

Bila nilai CR lebih besar dari nilai kritis maka dapat diduga bahwa distribusi data tidak normal. Nilai kritis dapat ditentukan berdasarkan tingkat signifikansi 0.01 (one tailed) yaitu sebesar \pm 2.33 (Hair et al, 1998).

\section{Evaluasi atas kriteria Goodness-of Fit}

Pada penelitian ini, pengujian absolute fit measures akan dilakukan dengan indeks kesesuaian chi-square statistics ( $\chi^{2}$ atau CMIN), GFI, dan RMSE dan pengujianincremental fit measures dilakukan dengan indeks kesesuaian AGFI dan CFI. Selanjutnya dilakukan pengujian dengan indeks kesesuaian normed chisquare (CMIN/DF).

\section{Asumsi Outliers}

Outliers dapat dievaluasi dengan nilai mahalanobis distance dengan nilai $d f$ sejumlah variabel yang dipergunakan dalam penelitian pada tingkat $\mathrm{p}<0.001$. Dalam hal ini variabel yang dimaksud adalah jumlah item pengukuran pada model.

\section{Evaluasi Hubungan Kausalitas}

Hubungan kausalitas dikatakan signifikan apabila nilai parameter estimasi kedua konstruk memiliki nilai C.R. $\geq \pm 2.00$ dengan taraf signifikasi sebesar 0.01 (1\%) (Hair et al., 1998).

\section{HASIL DAN PEMBAHASAN}

a. Analisis Deskriptif

Variabel Service Quality

Variabel Service Quality yang diteliti dalam penelitian ini menggunakan 22 indikator yang dikembangkan dari dimensi Service Quality.Adapun hasil perhitungan nilai indeks untuk variabel Service Quality disajikan dalam Gambar 3.

Gambar 2

Nilai Indeks Service Quality

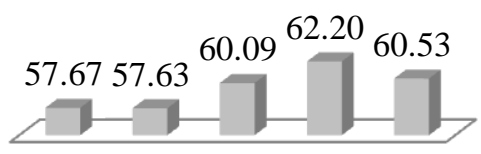

$$
\begin{gathered}
\text { RL RS A E } \quad \text { T } \\
\text { Indikator } \\
\text { Sumber: Data Olahan } 2013
\end{gathered}
$$

\section{Variabel Customer Satisfaction}

Dari ketujuh indikator kepuasan pada gambar 4 ini, indikator CS7 tentang perasaan senang bernilai indeks tinggi yaitu sebesar 69,0, sedangkan enam indikator lainnya bernilai indeks cukup. Artinya secara keseluruhan 
kepuasan wisatawan masih dirasa cukup.Sejauh ini, keinginan wisatawan dalam berekreasi yaitu kepuasan secara utuh.

Gambar 3

Nilai Indeks Costumer Satisfaction

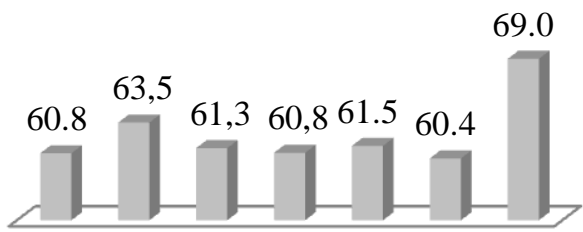

\section{CS1 CS2 CS3 CS4 CS5 CS6 CS7 Indikator}

Sumber: Data Olahan 2013

\section{Variabel Word of Mouth}

Adapun hasil perhitungan nilai indeks untuk variabel Words of Mouth (WOM) disajikan dalam gambar5 berikut ini.

Gambar 4

Nilai Indeks Word of Mouth (WOM)

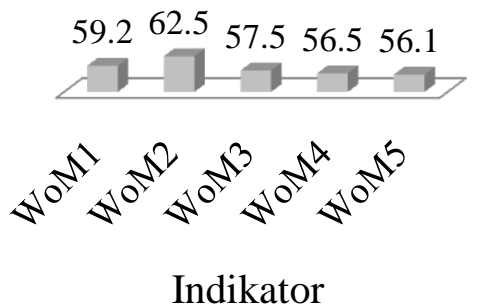

Sumber: Data Olahan 2013

Nilai indeks yang terendah pada gambar 10 yaitu WOM5 tentang kesediaan merekomendasikan taman rekreasi ini melalui facebook, twitter dan sms. Secara keseluruhan word of mouth berkisar 56,1-62,5 (cukup). Artinya kesediaan wisatawan merekomendasikan atau menceritakan taman rekreasi ini biasa saja.

\section{b. Analisis Inferensial}

\section{Uji Validitas}

Hasil uji validitas dalam penelitian ini dapat dilihat pada tabel 3. Penelitian ini menggunakan korelasi bivariate untuk menguji validitas instrumen penelitian. Dari tabel terlihat bahwa korelasi antar masing-masing indikator menunjukkan hasil yang signifikan.

Tabel 3. Hasil Uji Validitas

$\begin{array}{crcr}\text { Kode } & \text { Korelasi } & \text { Kode } & \text { Korelasi } \\ & & & \\ & \text { Pearson } & & \text { Pearson } \\ \text { RL1 } & 0.672 & \text { E5 } & 0.783 \\ \text { RL2 } & 0.737 & \text { T1 } & 0.805 \\ \text { RL3 } & 0.701 & \text { T2 } & 0.801 \\ \text { RL4 } & 0.776 & \text { T3 } & 0.691 \\ \text { RL5 } & 0.795 & \text { T4 } & 0.715 \\ \text { RS1 } & 0.753 & \text { CS1 } & 0.852 \\ \text { RS2 } & 0.772 & \text { CS2 } & 0.845 \\ \text { RS3 } & 0.844 & \text { CS3 } & 0.785 \\ \text { RS4 } & 0.819 & \text { CS4 } & 0.857 \\ \text { RS5 } & 0.783 & \text { CS5 } & 0.865 \\ \text { A1 } & 0.751 & \text { CS6 } & 0.807 \\ \text { A2 } & 0.760 & \text { CS7 } & 0.823 \\ \text { A3 } & 0.758 & \text { WOM1 } & 0.700 \\ \text { E1 } & 0.766 & \text { WOM2 } & 0.790 \\ \text { E2 } & 0.821 & \text { WOM3 } & 0.850 \\ \text { E3 } & 0.820 & \text { WOM4 } & 0.834 \\ \text { E4 } & 0.781 & \text { WOM5 } & 0.840\end{array}$

\section{Reliabilitas}

Berdasarkan data pada tabel 4 terlihat bahwa keseluruhan variabel telah memenuhi ketentuan yang berlaku.

Tabel 4

Cronbach's Alpha dari Konstruk

$\begin{array}{lccc}\text { Konstruk } & \begin{array}{c}\text { Jumlah } \\ \text { Item } \\ \text { dalam } \\ \text { Kuesioner }\end{array} & \begin{array}{c}\text { Jumlah item } \\ \text { yang } \\ \text { Dipertahankan }\end{array} & \begin{array}{c}\text { Cronbach's } \\ \text { Alpha }\end{array} \\ \begin{array}{l}\text { Service } \\ \text { Quality }\end{array} & 22 & 22 & 0.967 \\ \begin{array}{l}\text { Customer } \\ \text { Satisfaction }\end{array} & 7 & 7 & 0.925 \\ \begin{array}{l}\text { Word } \\ \text { of Mouth }\end{array} & 5 & 5 & 0.860\end{array}$




\section{Analisis Structural Equation Modelling}

Sebelum melakukan pengujian model structural dengan Structural Equation Modelling (SEM) terdapat beberapa asumsi yang harus diperhatikan, yaitu:

\section{Uji Kecukupan Sampel}

Jumlah total sampel yang digunakan dalam penelitian ini adalah 248 orang. Secara umum, jumlah sampel diatas 200 telah memadai untuk diuji menggunakan SEM. Menurut Hair et. all.,(1998) jumlah sampel minimum adalah 100 dan dinilai telah memenuhi kriteria minimal lima kali jumlah estimated parameter.

\section{Uji Normalitas}

Pengujian asumsi normalitas dapat dilakukan dengan metode statistik. Nilai statistik untuk menguji normalitas disebut $z$ value (Critical Ratio atau CR) dari ukuran kurtosis sebaran data.

Tabel 5.

Assessment of normality (Group number 1)

\begin{tabular}{lrrr}
\hline Variabel & \multicolumn{1}{c}{ c.r. } & kurtosis & c.r. \\
\hline WM1 & $-4,479$ &, 804 & 2,583 \\
WM2 & $-4,248$ &, 771 & 2,477 \\
WM3 & $-2,126$ &, 357 & 1,149 \\
WM4 & $-3,508$ &, 196 &, 631 \\
WM5 & $-1,871$ &,- 378 & $-1,214$ \\
CS7 & $-4,694$ &, 667 & 2,143 \\
CS6 & $-3,401$ & 1,026 & 3,300 \\
CS5 & $-3,431$ &, 166 &, 534 \\
CS4 & $-5,178$ & 1,101 & 3,539 \\
CS3 & $-3,803$ &, 286 &, 918 \\
CS2 & $-4,586$ &, 730 & 2,346 \\
\hline
\end{tabular}

\begin{tabular}{lccc}
\hline CS1 & $-2,474$ &, 193 &, 620 \\
SQ22 & $-3,760$ &, 281 &, 904 \\
SQ21 & $-3,356$ &, 338 & 1,087 \\
SQ20 & $-2,785$ &, 569 & 1,828 \\
SQ19 & $-3,899$ &, 714 & 2,296 \\
SQ18 & $-3,806$ &, 662 & 2,129 \\
SQ17 & $-4,106$ &, 364 & 1,171 \\
SQ16 & $-3,664$ &, 736 & 2,364 \\
SQ15 & $-3,561$ &, 366 & 1,176 \\
SQ14 & $-3,474$ &, 297 &, 956 \\
SQ13 & $-4,436$ &, 554 & 1,780 \\
SQ12 & $-4,072$ &, 401 & 1,288 \\
SQ11 & $-4,530$ &, 160 &, 513 \\
SQ10 & $-2,015$ &, 119 &, 384 \\
SQ9 & $-3,905$ &, 377 & 1,212 \\
SQ1 & $-2,974$ &, 150 &, 482 \\
SQ2 & $-4,099$ &, 342 & 1,100 \\
SQ3 & $-4,568$ &, 647 & 2,080 \\
SQ4 & $-3,063$ &,- 047 &,- 150 \\
SQ5 & $-1,993$ &, 072 &, 232 \\
SQ6 & $-3,749$ &, 469 & 1,508 \\
SQ7 & $-2,596$ &, 049 &, 156 \\
SQ8 & $-2,286$ &, 481 & 1,547 \\
Multiva & & 552,399 & 87,91 \\
\hline & & & \\
\hline
\end{tabular}

Bila nilai CR lebih besar dari nilai kritis maka dapat diduga bahwa distribusi data tidak normal. Nilai kritis dapat ditentukan berdasarkan tingkat signifikansi 0.01 (one tailed) yaitu sebesar \pm 2.33 (Hair et al, 1998). Pada tabel 5, tampak bahwa nilai critical ratio untuk skewness dan curtosis menunjukkan lebih banyak nilai lebih besar dari \pm 2.33 $(\mathrm{CR} \geq \pm 2.33$ ), hal ini berarti bahwa sebagian besar nilai critical ratio pada skewness maupun curtosis menunjukkan nilai yang tidak normal. Nilai $C R$ skewness maupun curtosis tidak dapat memenuhi asumsi normalitas data pada level $\alpha$ 
$=0.01$, baik secara univariate maupun multivariate, sehingga tampak bahwa data berdistribusi tidak normal.

Asumsi normalitas secara multivariate yang tidak bisa dipenuhi dalam pengujian dengan SEM dalam penelitian ini dapat diabaikan, karena data yang digunakan disajikan apa adanya dan didapat dari data primer yang didasarkan atas respon dari setiap individu yang sangat beragam. Namun analisis tetap dapat dilanjutkan dengan teknik maximum likelihood estimate mengingat teknik ini cukup robust, meskipun asumsi normalitas data tidak dapat terpenuhi (Chou dan Bentler, 1995 dalam Purwanto, 2002).

\section{Evaluasi atas kriteria Goodness-of Fit}

Evaluasi nilai goodness of fit dari model structural yang telah diestimasi disajikan padatabel 6 .

Tabel 6.

Hasil Goodness of Fit

$\begin{array}{cccc}\begin{array}{c}\text { Goodness of } \\ \text { Fit Index }\end{array} & \begin{array}{c}\text { Cut of } \\ \text { Value }\end{array} & \text { Hasil } & \text { Keterangan } \\ \text { Chi Square } & \text { Kecil } & 1823.99 & - \\ \text { GFI } & \geq 0.90 & 0.673 & \text { Marginal } \\ \text { RMSEA } & \leq 0.08 & 0.100 & \text { Marginal } \\ \text { AGFI } & \geq 0.90 & 0.629 & \text { Marginal } \\ \text { TLI } & \geq 0.90 & 0,810 & \text { Marginal } \\ \text { NFI } & \geq 0.90 & 0.769 & \text { Marginal } \\ \text { CFI } & \geq 0.95 & 0.823 & \text { Marginal } \\ \text { CMIN/DF } & \leq 2.00 / \leq & 3.481 & \text { Marginal } \\ & 3.00 & & \end{array}$

Dari indeks padatabel 6di atas, dapat disimpulkan bahwa seluruh kriteria memiliki goodness of fit yang kurang memenuhi persyaratan berdasarkan cut of value yang direkomendasikan. Nilai chi-square yang rendah dengan tingkat signifikansi lebih dari 0,05 atau 0,01 menunjukkan bahwa matriks input yang sebenarnya tidak berbeda dengan matriks input yang diprediksi
(Hair et al, 1998). Namun nilai chisquare dalam penelitian ini tinggi yaitu 1823.989 dan tingkat signifikansi 0.00. Dengan demikian matriks input yang sebenarnya berbeda dengan matriks input yang diprediksi. Faktor yang menyebabkan nilai chisquare tinggi adalah besarnya sampel yang digunakan.Indeks chi-square sangat sensitif terhadap perbedaan jumlah sampel.Untuk nilai RMSEA, CMIN/DF,AGFI, GFI, TLI, NFI dan CFI menunjukkan nilai kesesuaian yang marginal. Meskipun demikian nilai kesesuaian marginal tersebut tidak jauh berbeda dengan cut of valuenya, sehingga secara keseluruhan disimpulkan bahwa model struktural awal yang diestimasi dapat diterima.

\section{Asumsi Outliers}

Dalam penelitian ini jumlah variabel yang digunakan sebanyak 34 variabel. Dengan demikian, apabila terdapat nilai mahalanobis distance yang lebih besar dari $\chi 2$ (34, $0.001)=59.70$, maka nilai tersebut adalah outliers multivariate.

Tabel 7

Multivariate Outlier

\begin{tabular}{cccc}
\multicolumn{4}{c}{ Multivariate Outlier } \\
\hline $\begin{array}{c}\text { Observation } \\
\text { number }\end{array}$ & $\begin{array}{c}\text { Mahalanobis } \\
\text { d-squared }\end{array}$ & $\mathrm{p} 1$ & $\mathrm{p} 2$ \\
11 & 52,222 &, 024 &, 000 \\
139 & 51,627 &, 027 &, 000 \\
225 & 51,151 &, 030 &, 000 \\
25 & 50,746 &, 032 &, 000 \\
46 & 50,645 &, 033 &, 000 \\
11 & 52,222 &, 024 &, 000 \\
139 & 51,627 &, 027 &, 000 \\
225 & 51,151 &, 030 &, 000 \\
. &. &. & $\cdot$ \\
& & & \\
\hline
\end{tabular}




\begin{tabular}{lrrr}
\hline 189 & 31,941 &, 569 & 1,000 \\
163 & 31,807 &, 576 & 1,000 \\
\hline \multicolumn{2}{l}{ Berdasarkan } & data & padatabel
\end{tabular}

Berdasarkan data padatabel 7tampak tidak ada nilai observasi yang dianggap sebagai outliers multivariate.

\section{Evaluasi Hubungan Kausalitas}

Hubungan kausalitas dikatakan signifikan apabila nilai parameter estimasi kedua konstruk memiliki nilai C.R. $\geq \pm 2.00$ dengan taraf signifikasi sebesar 0.01 (1\%) (Hair et al., 1998).Hasil perhitungan regression weight pada model disajikan dalam Tabel 8.

Tabel 8

Structural Equation Model Regression Weight

\begin{tabular}{|c|c|c|c|c|c|}
\hline \multicolumn{3}{|c|}{ Regression Weight } & \multirow{2}{*}{$\begin{array}{r}\text { Estimate } \\
0.512\end{array}$} & \multirow{2}{*}{$\begin{array}{l}\text { S.E. } \\
0.136\end{array}$} & \multirow{2}{*}{$\begin{array}{l}\text { C.R. } \\
\quad 3.775\end{array}$} \\
\hline WOM & $<--$ & Servqual & & & \\
\hline WOM & $<-$ & Cussat & 0.449 & 0.134 & 3.355 \\
\hline Cussat & $<-$ & Servqual & 0.91 & 0.064 & 14.16 \\
\hline
\end{tabular}

Jika dilihat dari tabel 8tampak bahwa service quality berpengaruh signifikan terhadap word of mouth (WOM) dengan nilai CR 3,775. Artinya, kualitas jasa yang baik seperti keandalan, ketanggapan, jaminan, empati dan bukti langsung yang dilakukan petugas akan menciptakan WOM yang positif. Hal ini berlaku padataman rekreasi yang ada di kota Pekanbaru. Hasil penelitian ini mendukung hasil penelitian yang dilakukan oleh Harrison-Walker, 2001 yang menyatakan kualitas pelayanan berpengaruh positif terhadap WOM. Kemudian penelitian yang dilakukan oleh Reingen dan Walker (2001) dari hasil penelitiannya menghasilkan penelitian yang menunjukan WOM 7 kali lebih efektif dibandingkan iklan di majalah dan Koran, 4 kali lebih efektif dari personal selling serta 2 kali lebih efektif daripada iklan radio pada usaha yang dilakukan oleh perusahaan dalam mempengaruhi pelanggan untuk beralih menggunakan produk perusahaan tersebut.

Hipotesis kedua menyatakan kepuasan pelanggan berpengaruh positif terhadap perilaku word of mouth (WOM) juga terbukti dengan CR 3,355.Kotler dan Keller (2007) mendukung pendapat tersebut dengan menyampaikan pendapatnya bahwa harapan pelanggan terhadap suatu jasa dapat terbentuk oleh pengalaman masa lalu, WOM, dan promosi yang dilakukan oleh perusahaan jasa. Bowen (2001) juga dalam penelitian terhadap jasa hotel menemukan bahwa:

"the respondents who were very satisfied, strongly agreed that they would recommend the hotel which they were loyal too, when the topic of the hotel came up in conversation. But the results also show, that as Customer Satisfaction declines (from very satisfied, (7) to (6)) the willingness to communicate a positive message of the hotel dropped more than 50 percent".

Brown et al, 1997; Szymanski dan Henard 2001, dalam Luo dan Hamburg, 2007, Produsen berharap bahwa kepuasan pelanggan menciptakan perilaku pelanggan yang dapat membantu perusahaan menciptakan komunikasi yang lebih efektif. Sebagai contoh, kepuasan konsumen akan membentuk WOM yang positif bagi perusahaan.

Hipotesis ketiga menyatakan bahwa service qualityberpengaruh signifikan terhadap ustomer 
satisfaction juga terbukti dengan nilai CR 14,16. Responden mempunyai persepsi bahwa kualitas jasa yang baik padataman rekreasi yang ada di kota Pekanbaru dengan sendirinya menciptakan kepuasan kepada konsumen begitu juga sebaliknya. Babin, et al (2005) dalam studinya di Korea menyebutkan bahwa kualitas layanan (dalam studinya disebut hedonic value), berpengaruh positif bagi kepuasan konsumen (pelanggan).

Selanjutnya Chen (2007)
menyatakan bahwa dalam menciptakan kepuasan konsumen, perusahaan harus dapat meningkatkan kualitas layanannya (Service Quality).Kepuasan pelanggan dapat diciptakan melalui kualitas layanan yang diberikan oleh perusahaan kepada para pelanggannya. Semakin baik kualitas layanannya, akan semakin tinggi pula kepuasan pelanggan terhadap perusahaan tersebut. Tingginya kualitas layanan juga tidak lepas dari dukungan internal perusahaan, terutama dukungan dari sumber daya manusianya.

\section{PENUTUP}

\section{Kesimpulan}

Berdasarkan hasil analisis data dengan batuan software AMOS, diperolehbeberapa kesimpulan dalam penelitian ini, sebagai berikut:

1. Secara umum, wisatawan taman rekreasi kota Pekanbaru menyatakan bahwa baik service quality, costumer satisfaction dan perilaku WOM wisatawan bernilai cukup dengan rentang nilai score berkisar 50-60. Artinya ketiga konstruk tersebut belum mencapai nilai baik.
2. Service quality berpengaruh signifikan terhadap perilaku WOM wisatawan tamanrekreasi yang ada di kota Pekanbaru. Artinya jika kinerja service quality meningkat, maka akan meningkatkan intensitas WOM wisatawan taman rekreasi kepada pihak lain.

3. Costumer satisfaction berpengaruh signifikan terhadap perilaku WOM wisatawan tamanrekreasi yang ada di kota Pekanbaru, yang berarti bahwa jika wisatawan merasa puas maka wisatawan tersebut akan meningkatkan intensitas WOM mereka kepada pihak lain.

4. Service quality berpengaruh signifikan terhadap costumer satisfaction wisatawan tamanrekreasi yang ada di kota Pekanbaru. Artinya jika kinerja service quality meningkat, maka akan meningkatkan costumer satisfaction wisatawan taman rekreasi kepada pihak lain.

5. Dari kedua variabel tersebut, costumer satisfaction yang paling berpengaruh terhadap intensitas WOM wisatawan taman rekreasi yang ada di kota Pekanbaru.

\section{Saran}

Dari hasil penelitian yang telah dilakukan oleh peneliti, ada beberapa saran yang diajukan yaitu:

1. Perlunya pengelola taman rekreasikota Pekanbaru meningkatkan kinerja service quality wisatawan sehingga menciptakan WOM yang positif kepada pihak lain.

2. Perlunya pengelolataman rekreasikota Pekanbaru meningkatkan 
costumersatisfaction wisatawan untuk menciptakan intensitas WOM kepada pihak lain.

3. Diharapkan pengelola menambah fasilitas untuk wisatawan taman rekreasi kota Pekanbaru.

\section{DAFTAR PUSTAKA}

Babin, Barry J, et al. 2005. "Modelling Consumer Satisfaction and Word-ofMouth: Restaurant Patronage in Korea", The Journal of Services Marketing; 19,3. ABI/INFORM Global

Blodget, J.G. Granbois, D.H and Walters, R.G., (1993), "The Effect of Perceived Justice on 'Comlainants' Negative Wordof-Mouth Behaviour and Reppatronage Inventions", Journal of Retailing, Vol. 69, No. 4, (dalam Mangold, 1999; 75).

Boulding, W. , Kalra, A. , Staelin, R. and Zeitharal, V.A. 1993, "A dynamic process model of service quality: from expectations to behavioral intentions", Journal of Marketing Research, Vol. 30. February, pp. 7-27

Bowen, John T. And Shiang-Lih Chen, (2001), "The Relationship between Customer Loyalty and Customer Satisfaction", International Journal of Contemporary Hospitality Management, 13/15, MCB University Press.

Brown, Tom J \& Dacin, Peter A., 1997, "The Company and The Product:Corporate Association and Consumer
Product Responses", Journal of Marketing, January, pg. 68-84

Chaniotakis, E. and Lymperopoulus C. 2009. Service Quality Effect on atisfaction and Word of Mouth in The Health Care Industry, ManagingService Quality, Vol. 19, No. 2, pp $229-242$

Chew, Patricia and Jochen Wirtz, (2001), "The Effects of Incentives, Deal Proneness, Satisfaction and Tie Strength on Word-of-Mouth Behaviour", Research Paper Series, NUS Business School, National University of Singapore.

Chen, Cheng-Nan, 2007, The

Relation among Social Capital,

Entrepreneurial

Orientation, Organizational Resources and Entrepreneurial Performance for New Ventures, Contemporary Management Research, National Cheng Kung University.

Cooper, Donald R., Pamela S. Schlindler, (2003), "Business Research Methods", Eight Edition, McGrow-Hill, USA.

Fandi Tjiptono, (2002), "Manajemen Jasa", Penerbit ANDI, Yogyakarta.

Flintoff, John-Paul. 2002. When The Buzz is not Quite What it Seems. Financial Times, London

Freddy Rangkuti. 2002. Measuring Customer Satisfaction. 
Jakarta: Gramedia Pustaka Utama

Goodman, John. 2005. Treating Your Customers as Your Media Reps. www.brandweek.com

Gwinner, Kevin P., Dwayne D Gremler and Marry Jo Bitner, 1998, "Relational Benefits In Services Industries: The Customer's Perspective", Journal of The Academy of Marketing Science, 26 (Spring), 101-14

Harrison, L. Jean -Walker, 2001," The Measurement of Word Of Mouth Communication And An Investigation of Service Quality And Customer Commitment As Potential Antecedents", Journal of Service Research, Vol. 4, No. 1, p. 60-75

Kotler, Philip, (2003), "Marketing Management" International Edition, Eleventh Edition, Prentice Hall Pearson Education International, Inc.

Kotler , P. dan Keller , K.L. 2007. Manajemen Pemasaran, Edisi Kedua Belas Jilid 1. Edisi Bahasa Inggris. Pearson Education, Inc. Upper Saddler River, New Jersey, 07458, Edisii Bahasa Indonesia, pada PT. INDEKS

Manajemen Pemasaran, Edisi Kedua Belas Jilid 1. Edisi Bahasa Inggris. Pearson Education, Inc. Upper Saddler River, New Jersey, 07458, Edisii Bahasa Indonesia, pada PT. INDEKS
Kotler, P, 2000, Marketing Management : Analysis, Planning, Implementation and Control, Prentice Hall International Inc, New Jersey

--------, (2003), “Marketing Management", International Edition,. Millenium Edition, Prentice Hall International, Inc.

Lovelock, Christoper, (2001), "Service Marketing", People, Technology, Strategy, International Edition, Fourth Edition, Prentice Hall International, Inc.

Luo, Xieming \& Homburg, Christian, 2007, "Neglected Outcomes of Customer Satisfaction", Journal of Marketing, April 2007

Mangold, W. Glyn, Fred Miller and Garry R. Brockway, (1999), "Word-of-Mouth Communication in Service Marketplace", The Journal of Service Marketing, Vol. 13, No. 1, MCB University Press, Kentucky, USA.

Parasuraman, A., Leonard L. Berry, (1991), "Marketing Service, Competing Through Quality". The Free Press, A Division of Memillan, Inc, New York.

Payne, Adrian, (1993), "The Essence of Service Marketing". Prentice Hall, New York.

Salomon, Micheal R., (1999), "Cunsomer Behaviour" Fourth Edition, International Edition, Prentice Hall. 
Sekaran, Uma, (2000), "Research Methods For Business". A Skill Building Approach, Third Edition, John Willey and Sons, Inc.

Silverman, George, (2003), "How to Harness Word-of-Mouth: Guide to Peer Selling", Market Navigation, Inc, Http:/www.mnav.com/wom.h tm.

Sivalas, Eugne and Jamie L. Baker-Prewitt, (2000), "An Examinationa of the Relationship Between Service Quality, Customer Satisfaction and Store Loyalty", International Journal of Retail \& Distribution Management, Vol. 28, No. 2, MCB University Press.

Steinhoff, Dan, (1979), "The World of Business". McGrow-Hill Book Co.

Taylor, Gail Ayala, (2001), "Coupon Response in Service", Journal of Retailing, No. 77, Northwestern University, USA.

Tschohl, John. 2003, Achieving Excelence Through Customer Service, Unggul Bersaing Melalui Layanan Pelanggan. Jakarta: PT. Gramedia Pustaka Utama

Wargenhein, Florian V., Thomas Bayon, (2001), "Satisfaction, Loyalty and Word-of-Mouth within aFirm's Customer Base: Differences between Stayers, Switchers and Referal Switchers", Working Paper, Bruchsal, October
2001, International University in Germany.

Zethaml, Valerie A. and Mary Jo Bitner, (2000), "Service Marketing", Integrating Customer Focus Across the Firm, International Edition, Second Edition, McGrowHill Higher Education, USA.

www.hertantowidodo.com, 2008 "10 Karakter Unik Konsumen Indonesia", Majalah Marketing Edisi Khusus. 